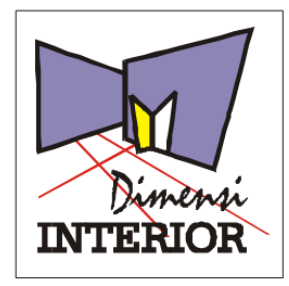

http://dimensiinterior.petra.ac.id

\title{
Eksperimen Perancangan Elemen Pembentuk Dan Pengisi Ruang Interior Berbasis Repurposing Pipa PVC
}

\author{
Jonathan Pramono | Yusita Kusumarini | Jean F. Poillot \\ Program Studi Desain Interior, Universitas Kristen Petra, Surabaya \\ Email: jonathanpramono@gmail.com
}

\begin{abstract}
ABSTRAK
Pipa PVC adalah bahan bangunan yang sangat umum digunakan dalam instalasi plumbing di seluruh dunia sejak tahun 1930. Dengan karakter fisik yang ringan, kuat, fleksibel, tahan terhadap kebocoran dan korosi, serta mudah dari segi perakitan, sifat fisik pipa PVC ini sangat potensial digunakan dalam perancangan elemen pembentuk dan pengisi ruang interior dengan prinsip "repurposing". Dalam perancangan ini terdapat 2 pokok masalah yang diangkat yakni bagaimana potensi pipa PVC dalam perancangan elemen pembentuk dan pengisi ruang interior dan apa saja kekurangan dan kelebihan dari rancangan elemen pembentuk dan pengisi ruang interior yang menggunakan pipa PVC sebagai bahan utamanya jika ditinjau dari sifat material pipa PVC, penerapan sistem mekanis, dan modularnya. Metode yang digunakan adalah design thinking dengan tahapan: inspiration (understand, observe, dan P.O.V.), ideation (ideate, prototype, dan test), implementation (story telling, pilot, dan business model). Perancangan ini menghasilkan 5 desain produk interior (chair, office table, coffee table, partisi, dan stacking rack). Kelima produk ini dapat membuktikan potensi pipa PVC dari segi sifat material dan penerapan sistemnya. Kelebihan yang teridentifikasi adalah: waktu pembuatan yang singkat serta sistem mekanis dan modular yang dapat diaplikasikan dengan sambungan dan tabung pipa PVC. Kekurangan yang teridentifikasi adalah aplikasi sistem dan proses perakitan yang kurang bisa presisi.
\end{abstract}

Kata Kunci: pipa PVC, refunction, elemen pembentuk, elemen pengisi, ruang interior, eksperimen, modular.

\begin{abstract}
PVC pipes are the most common building materials used in plumbing plants around the world since 1930. With a lightweight, strong, flexible, leak-proof and corrosion-resistant, and easy-to-assemble nature, the physical properties of these PVC pipes are potentially used in designing the interior forming and filling elements with the principle of "repurposing". In this design there are 2 main issues raised: how the potential of PVC pipes in the design of forming elements and interior space fillers and what are the advantages and disadvantages of the design of forming elements and interior space fillers that use PVC pipes as the main material when viewed from PVC pipe material properties, application of mechanical systems, and modular. The method used is design thinking with stages: inspiration (understand, observe, and P.O.V.), ideation (ideate, prototype, and test), implementation (story telling, pilot, and business model). This design produces 5 interior product designs (chair, office table, coffee table, partition, and stacking rack). These five products can prove the potential of PVC pipes in terms of material properties and application of the system. The strengths identified are: short manufacturing times and mechanical and modular systems that can be applied with PVC pipe joints and tubes. The disadvantages identified are system applications and assembly processes that a re less precise.
\end{abstract}

Keywords: PVC pipe, refunction, element of form, element of fill, interior spaces, experiment, modular.

\section{PENDAHULUAN}

Pipa PVC adalah bahan bangunan yang sangat umum digunakan dalam instalasi plumbing di seluruh dunia sejak tahun 1930. Pipa PVC memiliki berbagai keunggulan untuk menggantikan instalasi pipa sebelumnya yang terbuat dari logam. Berbeda dengan logam, material pipa
PVC memiliki karakter material yang ringan, kuat, fleksibel, tahan terhadap api, kebocoran, dan korosi, serta mudah dari segi perakitan sehingga material ini sangat ideal dalam menjalankan fungsinya. Keunggulankeungulan dari sifat fisik pipa PVC tersebut sebenarnya sangat sesuai sesuai dengan ciri-ciri material yang ideal 
dalam pembuatan elemen pembentuk dan pengisi interior. Dasar-dasar material pipa PVC inilah yang mendorong penulis untuk menggali potensi pipa PVC lebih jauh dari fungsi awalnya sebagai instalasi plumbing menjadi komponen elemen pembentuk dan pengisi ruang interior dengan prinsip "repurposing".

Repurposing dengan menggunakan pipa PVC menjadi elemen pembentuk dan pengisi ruang interior diharapkan dapat menjadi salah satu material alternatif pembentuk elemen interior yang lebih praktis dan sustainable untuk menjawab tantangan terhadap tuntutan inovasi dan environment problem yang ada saat ini. Beberapa topik permasalahan yang diangkat, antara lain berkaitan dengan bagaimana potensi pipa PVC dalam perancangan elemen pembentuk dan pengisi ruang interior? Serta apa saja kekurangan dan kelebihan dari rancangan elemen pembentuk dan pengisi ruang interior yang menggunakan pipa PVC sebagai bahan utamanya jika ditinjau dari sifat material pipa PVC, penerapan sistem mekanis, dan modular?

Untuk menjawab permasalahan yang diuraikan pada paragraph sebelumnya, penulis mengembangkan metode design thinking dari d'School Paris dengan tahapan sebagai berikut:

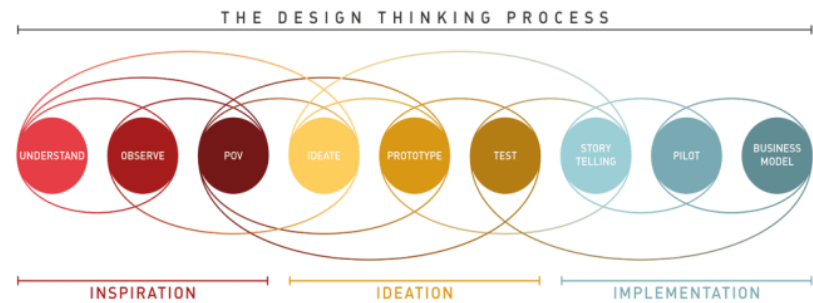

Gambar 1. Design Thinking d'School Paris

\section{DESIGN THINKING PROCESS}

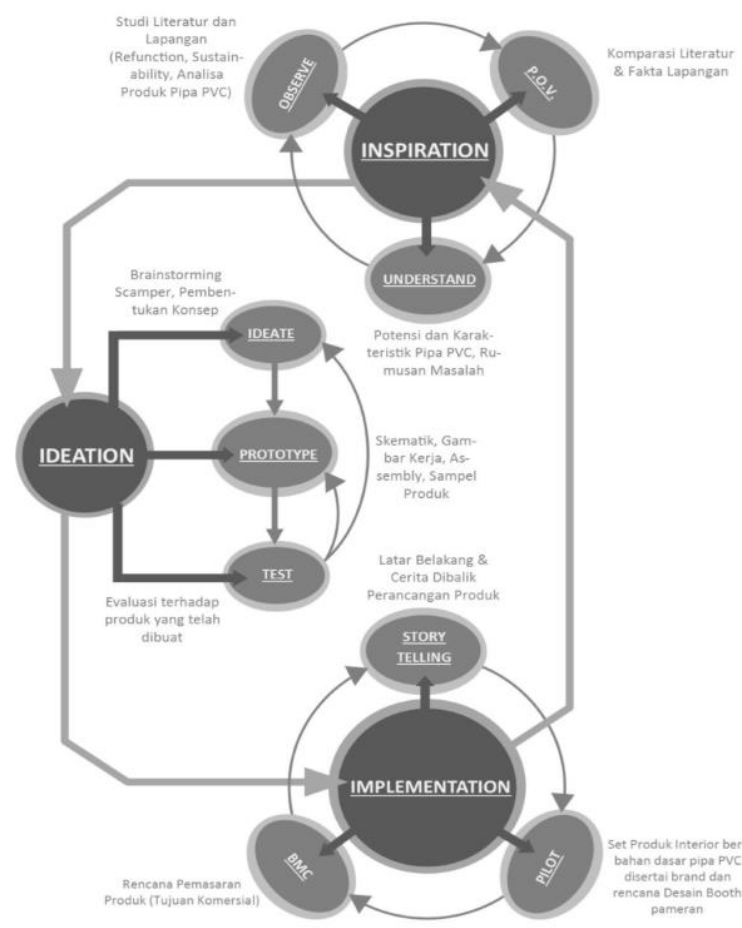

Gambar 2. Hasil Pengembangan Design Thinking d'School Paris

\section{- Understand}

Merupakan tahap dimana penulis melihat potensi sifat fisik pipa $P V C$ untuk dijadikan elemen pembentuk dan pengisi ruang interior. Selain potensi dari sifat fisik pipa $P V C$, penulis juga mengaitkan potensi "repurposing" pipa PVC sebagai solusi dari permasalahan lingkungan yang terjadi saat ini.

\section{- Observe}

Merupakan tahap dimana penulis mencari data-data terkait untuk mendukung proses perancangan produk berupa elemen pembentuk dan pengisi ruang interior berbahan dasar pipa $P V C$.

- P.O.V. (Point of View)

Merupakan tahap dimana penulis mengidentifikasi dan menentukan target market dari produk berupa elemen pembentuk dan pengisi ruang interior yang akan dirancang.

\section{- Ideate}

Merupakan tahap dimana penulis memunculkan sebanyak mungkin ide sebagai solusi dari rumusan masalah yang telah dibuat. Berbagai ide dan solusi yang telah dirumuskan akan disusun dan disortir lagi untuk menciptakan konsep sebagai dasar perancangan produk yang ideal.

\section{- Prototype}

Merupakan tahap pembuatan skematik desain berupa sketsa-sketsa dan mock-up dari set produk berupa elemen pembentuk dan pengisi ruang interior secara detail. Tahap ini juga meliputi eksperimeneksperimen terkait konstruksi dan teknik pembuatan item-item dalam set produk interior berbahan dasar pipa $P V C$. Sketsa dan mock-up desain kemudian direalisasikan menjadi sampel produk 1:1 lengkap dengan gambar kerja.

\section{- Test}

Merupakan rangkaian proses evaluasi terhadap seluruh hasil prototype (skematik, gambar kerja, dan sampel produk) yang telah dibuat pada tahap sebelumnya.

\section{- Story Telling}

Tahap implementasi desain yang menekankan latar belakang dan proses/cerita di balik pembuatan produk berupa elemen pembentuk dan pengisi ruang interior berbahan dasar pipa $P V C$.

\section{- Pilot}

Merupakan tahap implementasi yang dapat menginspirasi masyarakat untuk melakukan repurposing dengan produk elemen interior dari pipa $P V C$ sebagai pelopornya.

- Business Model Canvas

Bussiness Model Canvas karya perancangan tugas akhir dibuat untuk tujuan komersial (upaya pembentukan industri kecil produk interior).

\section{TINJAUAN PUSTAKA}

\section{A. Definisi Repurposing}

Repurposing adalah menciptakan kebaruan atau kehidupan kedua untuk produk yang telah ada/telah dibuat dengan membuat beberapa transformasi untuk produk tersebut. Repurposing mulai dilakukan secara 
massal pada masa perang Jerman di mana pakaian anakanak dibuat dari seragam tentara dan papan petunjuk dibuat dari alumunium bekas (Brandes, Stich, and Wender, 2009: 42). Pasca perang Jerman, repurposing pada botol dan minuman cola pun dilakukan di beberapa tempat. Di meksiko, minuman cola digunakan untuk pembersih saluran air sedangkan di Jepang, botol minuman cola dipakai di altar sebagai symbol [1].

Repurpose cukup identik dengan reuse, yakni menggunakan suatu produk lebih dari satu kali untuk menghemat waktu, uang, dan energi. Perbedaan pada repurpose dan reuse adalah bahwa pada repurpose, suatu produk digunakan untuk tujuan yang lain sehingga membutuhkan beberapa modifikasi untuk menjalankan tujuan [1].

\section{B. Keuntungan Repurposing}

Dalam jurnalnya yang berjudul Design for Repurposing: A Sustainable Design Strategy for Product Life and Beyond, Agguire mengungkapkan bahwa repurposing memiliki beberapa keuntungan. Keuntungan pertama terkait dengan penghematan energi karena repurposing membutuhkan energi pengolahan yang jauh lebih kecil jika dibandingkan dengan energi yang dibutuhkan untuk mendapatkan dan mengangkut material mentah dari sumbernya. Repurposing juga menghemat energi yang seharusnya dipakai untuk daur ulang suatu produk. Keuntungan kedua terkait dengan lingkungan dimana repurposing membantu lingkungan meminimalisir energi yang biasanya dihabiskan untuk produksi industrial dan daur ulang produk di mana keduanya menghasilkan zat polutan yang mencemari lingkungan [1].

Keuntungan ketiga berkaitan dengan manfaat ekonomi karena repurposing tidak memerlukan biaya yang biasa dikeluarkan untuk mengolah bahan mentah menjadi produk yang meliputi seluruh siklus produksi mulai dari memperoleh bahan baku, pendistribusian dari asal menuju tempat produksi, biaya proses \& manufaktur, serta disposal costs. Selain itu, repurposing tidak memerlukan lahan untuk pengolahan limbah. Sebagian besar site TPA diisi dengan banyak produk limbah pabrik. Beberapa bahan limbah ini adalah non-biodegradable yang terurai dalam jangka waktu yang sangat lama. Repurposing dapat menghemat space untuk pengolahan limbah-limbah jenis ini [1].

\section{Karakteristik Pipa PVC}

Dalam Handbook of PVC Pipe Design and Construction yang dikeluarkan Industrial Press Inc., Pipa $P V C$ memiliki beberapa keunggulan fisik yang sangat mendukung dalam perancangan, antara lain:

\section{- Ketahanan/ Durability}

Pipa $P V C$ adalah bahan non-konduktor listrik dan kebal terhadap reaksi elektrokimia yang disebabkan oleh asam, basa, dan garam. Sifat ini terdapat pada setiap bagian $P V C$ baik bagian dalam maupun luar sehingga tidak memerlukan aplikasi lapisan pelindung. Pipa juga $P V C$ tahan terhadap semua zat kimia rumah tangga dan sebagian besar zat kimia industrial pada temperature sekitar $140 \mathrm{oF}$. Selain terhadap reaksi elektrokimia, pipa PVC juga memiliki ketahanan terhadap tarikan karena memiliki elastisitas [2].

- Ringan

Pipa $P V C$ lebih ringan dibanding pipa dengan material pipa lain seperti besi, 1 orang dapat dengan mudah membawa 2 buah pipa PVC 4 inchi dengan panjang 20 kaki. Sifat $P V C$ yang ringan ini sangat aman digunakan untuk industri, mudah dari segi handling, dan dapat mengurangi tingkat kecelakaan saat proses instalasi [2].

\section{- Tahan Air}

Pipa $P V C$ terkonstruksi dari material yang kedap air ditambah dengan adanya lapisan plastik pada permukaan luar dan dalam tabung serta sambungannya [2].

- Sistem Sambungan

Instalasi pipa $P V C$ sangat mudah karena didukung dengan variasi joint system. Joint system pada pipa $P V C$ adalah deep insertion joint yang bersifat kedap air sehingga tidak memerlukan banyak treatment untuk mengatasi kebocoran saluran [2].

- Dimensi Panjang

Pipa $P V C$ dapat diproduksi dengan panjang hingga 20 kaki sehingga dapat meminimalkan penggunaan joint. Penggunaan joint yang minimal tentunya akan membuat proses instalasi lebih mudah dan efisien [2].

- Strength

Pipa $P V C$ memiliki ketahanan yang sangat baik terhadap benturan (karena memiliki kelenturan) jika dibandingkan dengan pipa beton dan pipa tanah liat. Pipa $P V C$ juga mampu menahan terjadinya retak dan pecah saat menahan beban melebihi kapasitas kekuatan maksimalnya [2].

\section{- Environmental Benefit}

Pipa $P V C$ merupakan salah satu produk yang sangat sustainable, proses pembuatannya tidak nyaris tidak menghasilkan limbah dan memiliki usia pakai yang sangat lama (awet). Pipa $P V C$ juga memungkinkan untuk didaur ulang [2].

\section{Tipologi Perancangan}

Karya perancangan ini dikembangkan dari beberapa tipologi produk interior berbahan dasar pipa $P V C$ yang diambil dari beberapa hak paten keluaran Amerika. Hak paten yang diambil berupa uraian pembuatan produk seperti seperti PVC swivel chair karya Arthur Kwlmderlich [3], PVC foldable chair karya B. Bruce Livington [4], dan PVC rocking chair karya Randy L. Tenbl'oeck [5]. Dasar-dasar pembuatan tipologi produkproduk tersebut kemudian dikembangkan dengan menambahkan aplikasi sistem modular, aplikasi sistem mekanis, dan penerapan berbagai metode finishing.

\section{PROGRAM PERANCANGAN}

Perancangan produk tugas akhir ini didahului beberapa eksperimen terkait sistem mekanis berupa mekanisme putar dan geser yang memanfaatkan sambungan dan tabung pipa pipa $P V C$. 


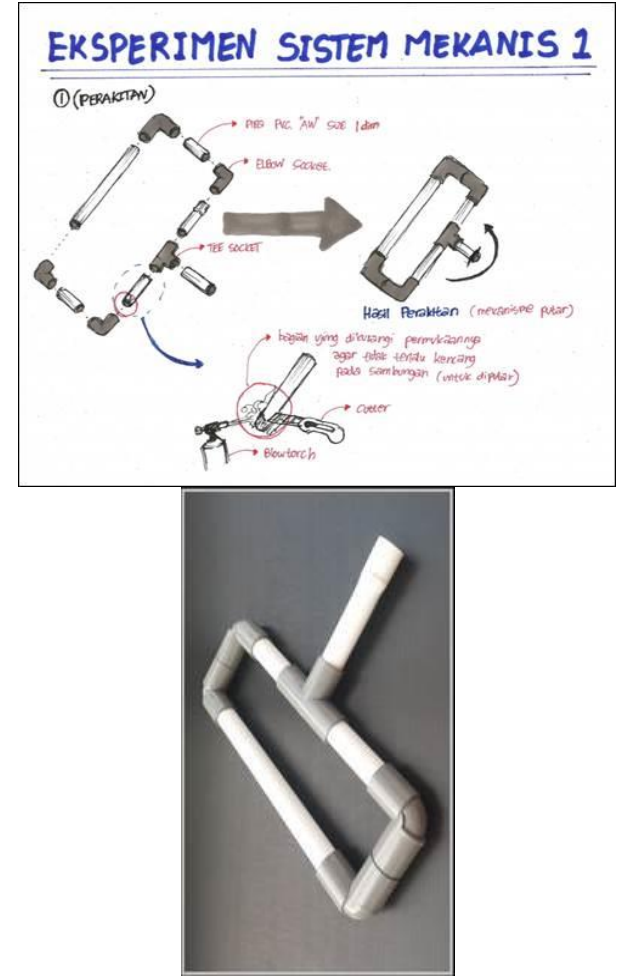

Gambar 3. Sketsa dan Hasil Eksperimen Sistem Mekanisme Putar.
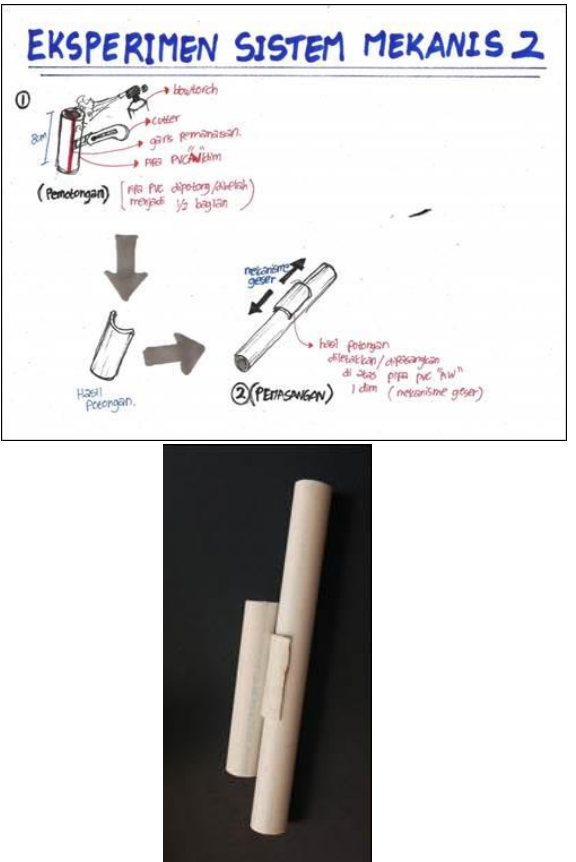

Gambar 4. Sketsa dan Hasil Eksperimen Sistem Mekanisme Geser.

Selain eksperimen pada sistem mekanis, eksperimen terkait finishing terhadap pipa $P V C$ dan sambungannya juga dilakukan. Proses eksperimen menghasilkan 7 jenis aplikasi finishing antara lain finishing ivory, solid black, wooden brown, wooden akasia, dark brown, burnt crack dan lite.

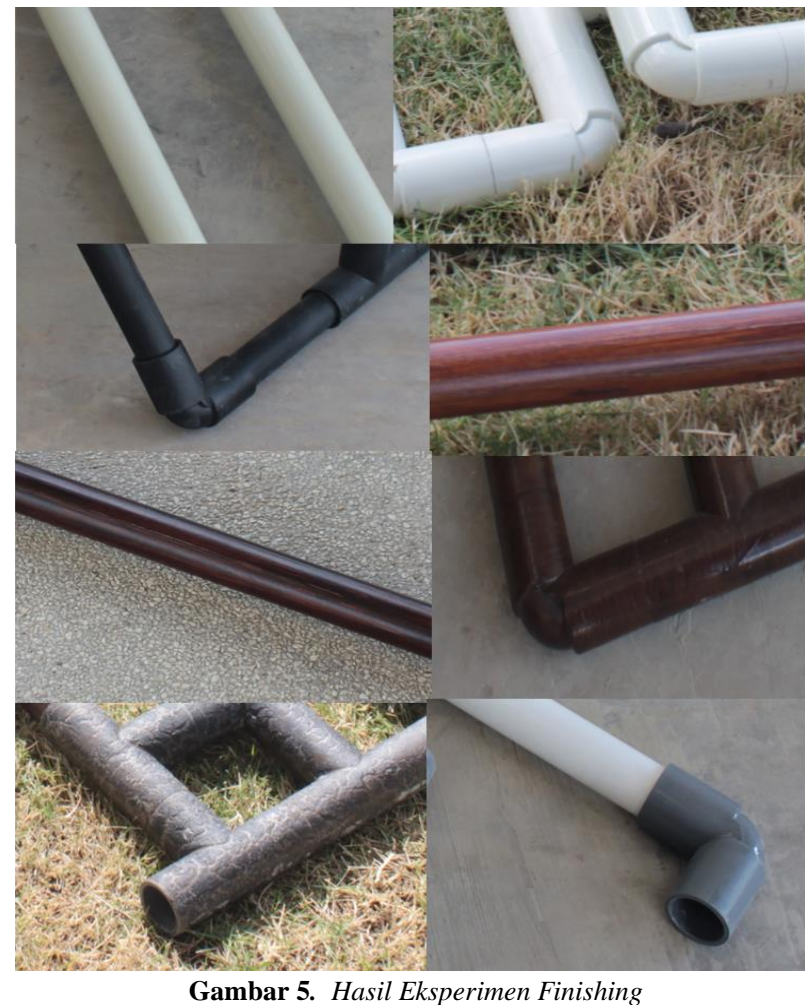

\section{KONSEP PERANCANGAN}

Secara garis besar, perancangan ini ditujukan untuk mengembangkan potensi material pipa $P V C$ dalam dunia produk interior. Penulis memberikan poin inovasi dengan sistem mekanis dan penerapan 7 jenis finishing yang berbeda pada masing-masing produk. Semua inovasi yang diterapkan pada produk merupakan penerapan hasil eksperimen yang telah dilakukan sebelumnya.

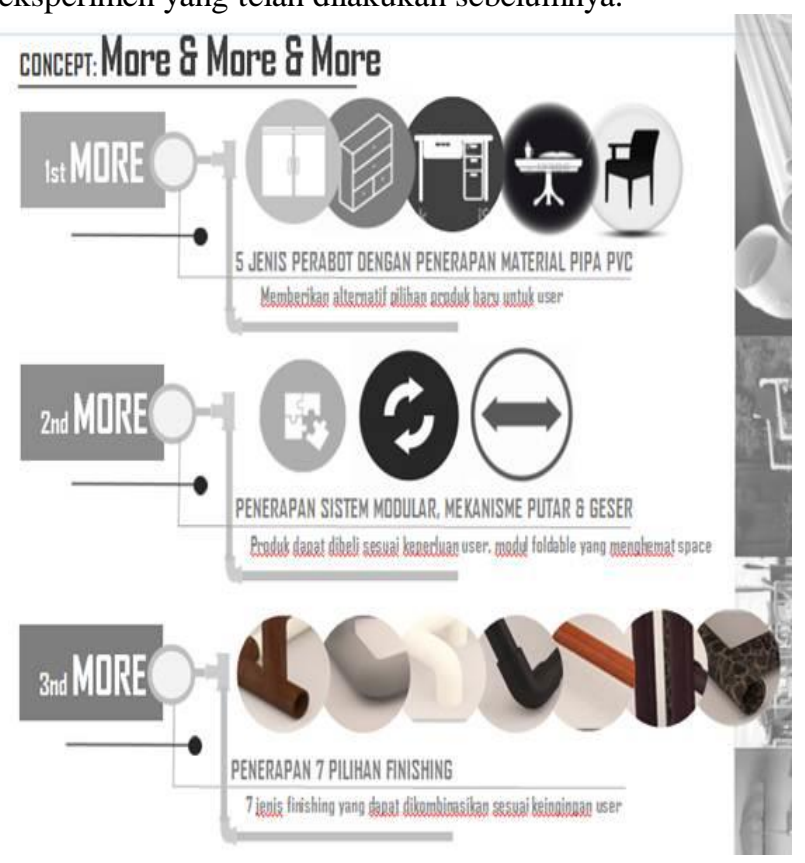

Gambar 6. Ilustrasi Konsep Perancangan

\section{PENGEMBANGAN DAN DESAIN AKHIR}

Dalam perancangan ini, terdapat 5 produk yang dihasilkan dengan menerapkan sistem modular beserta sistem mekanisme putar dan geser. Semua produk ini 
disempurnakan dengan aplikasi 7 jenis finishing yang berbeda, berikut adalah uraian skematik hingga desain akhir produk-produk berbahan dasar pipa $P V C$ yang dihasilkan:

\section{PVC Chair \& Short Stool}

Produk ini terdiri dari modul utama berupa short stool yang sudah bersifat fungsional dan modul tambahan berupa backseat. Modul backseat dapat ditambahkan pada short stool untuk mengingkatkan fungsi dan kenyamanan, dengan kata lain mengubah short stool menjadi kursi multipurpose. Modul backseat dipasangkan pada short stool dengan bantuan modul pengunci (top lock dan bottom lock). PVC chair dan short stool dirancang dengan kombinasi finishing burnt crack pada komponen sambungan (joint) dan wooden akasia pada komponen lonjor pipa $P V C$. Selain pipa $P V C$ sebagai bahan utama, $P V C$ chair \& short stool juga menggunakan material tambahan seperti busa, brown synthetic leather dan multipleks.

\section{FASTLITAS DUDUK \\ SET 1}

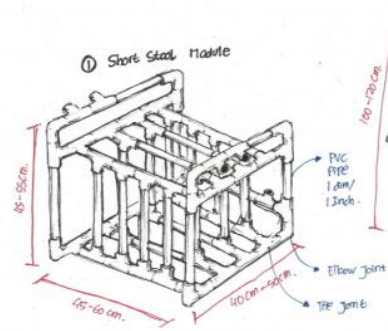

Gambar 7. Sketsa PVC Chair \& Short Stool

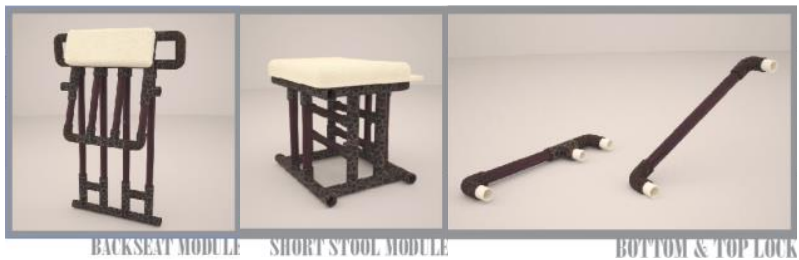

Gambar 8. Rendering Modul-modul PVC Chair \& Short Stool

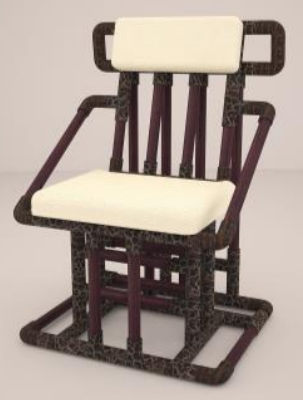

Gambar 9. Rendering PVC Chair

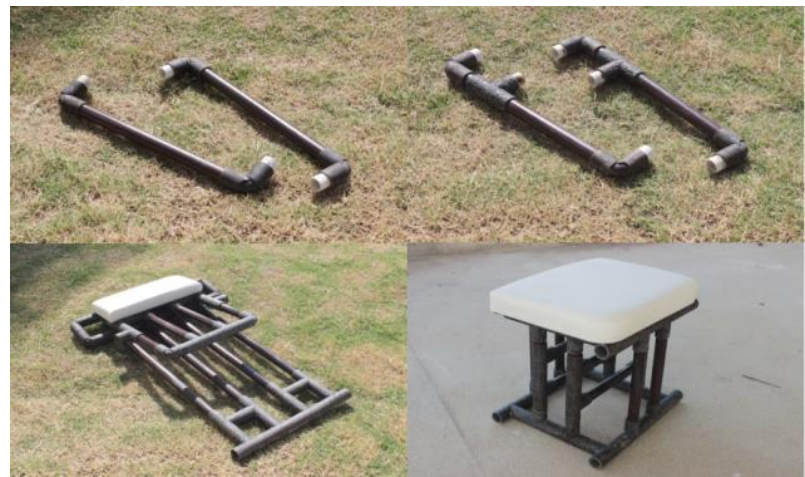

Gambar 10. Hasil Produksi Modul-modul PVC Chair \& Short Stool

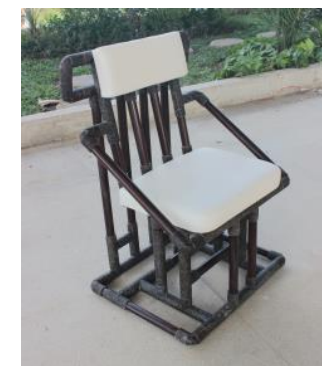

Gambar 11. Hasil Produksi PVC Chair

\section{PVC Office Table}

PVC office table terdiri dari 3 modul, yakni top table, leg module, dan drawer leg. Ketiga modul ini dirancang dengan kombinasi finishing ivory pada komponen sambungan (joint) dan wooden brown pada komponen lonjor pipa PVC. Leg module dan drawer leg dibuat dengan menerapkan sistem mekanisme putar sehingga bersifat foldable. Khusus untuk drawer leg, mekanisme tambahan berupa sistem geser juga ditambahkan sebagai pengganti rel laci. Produk ini juga memiliki beberapa komponen bidang yang terbuat dari multipleks dengan finishing HPL taco TH1211.

\section{OFFICE TABLE}

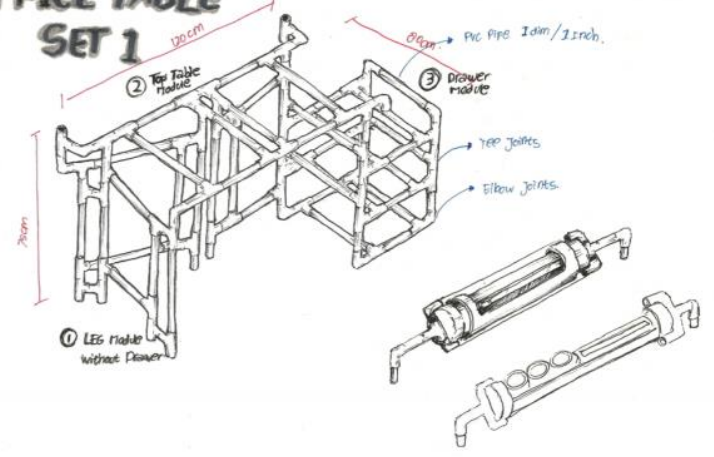

Gambar 12. Sketsa PVC Office Table

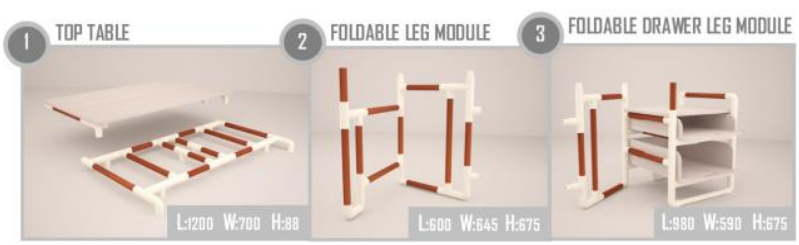

Gambar 13. Render Modul-modul PVC Office Table 

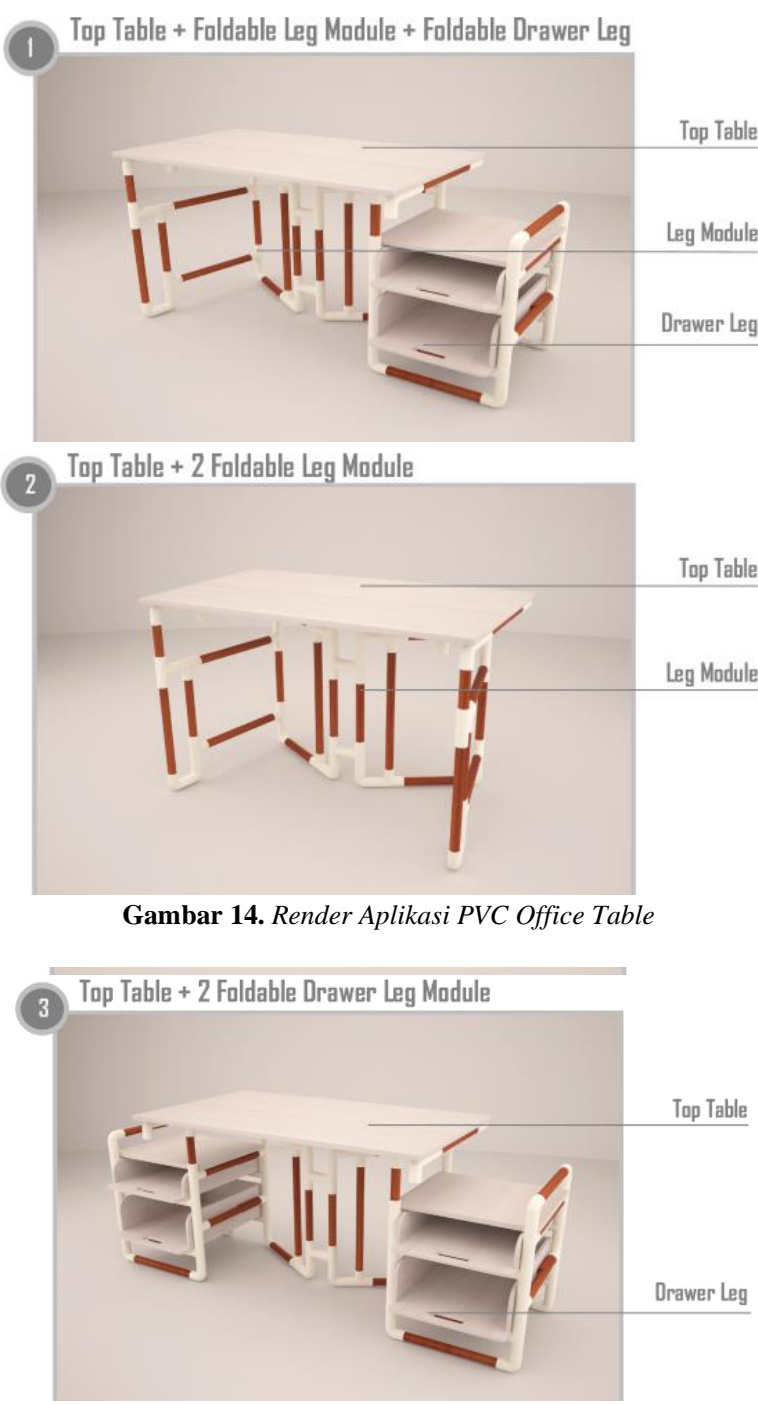

Gambar 15. Render Aplikasi PVC Office Table

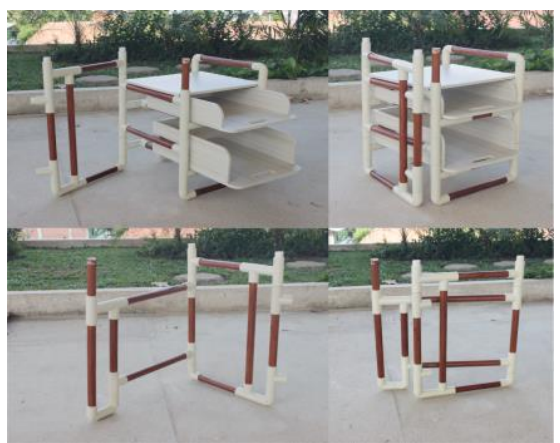

Gambar 16. Hasil Produksi Modul-modul PVC Office Table

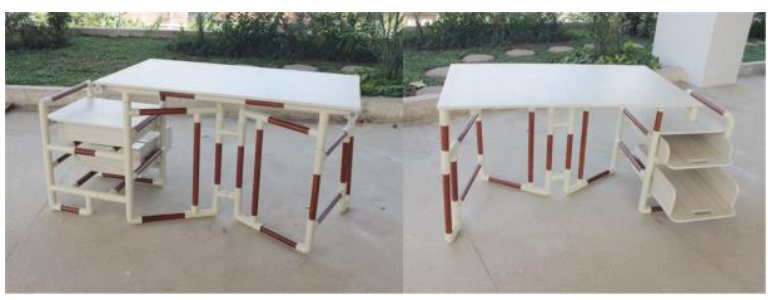

Gambar 17. Hasil Produksi PVC Office Table

\section{PVC Coffee Table}

PVC coffee table terdiri dari modul utama berupa center table serta 2 modul tambahan berupa side table, dan bottom rack module yang diberi finishing solid black. Adanya modul tambahan berupa side table dan bottom rack module ditujukan agar user dapat menambah luasan permukaan top table dan mengaplikasikan storage sesuai kebutuhan. Modul center table dan side table juga dilengkapi dengan penerapan mekanisme putar sehingga bersifat foldable. Produk ini juga menggunakan beberapa komponen bidang yang terbuat dari akrilik.

\section{BIDANGKERJA}

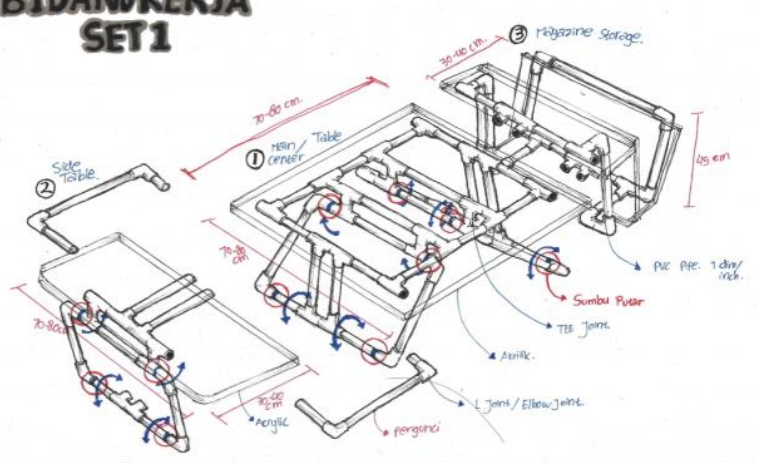

Gambar 18. Sketsa PVC Coffee Table

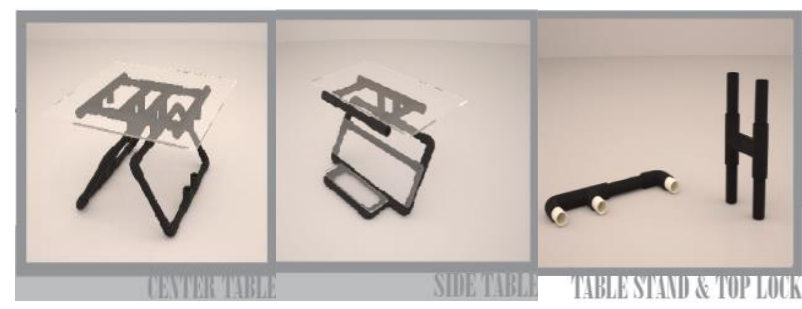

Gambar 19. Render Modul-modul PVC Coffee Table

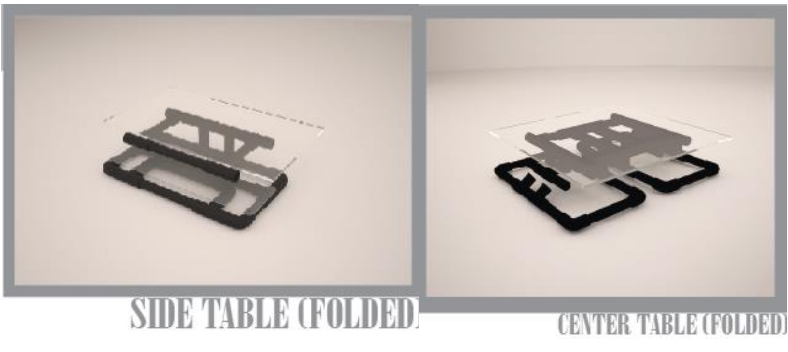

Gambar 20. Side Table \& Center Table (Folded) 


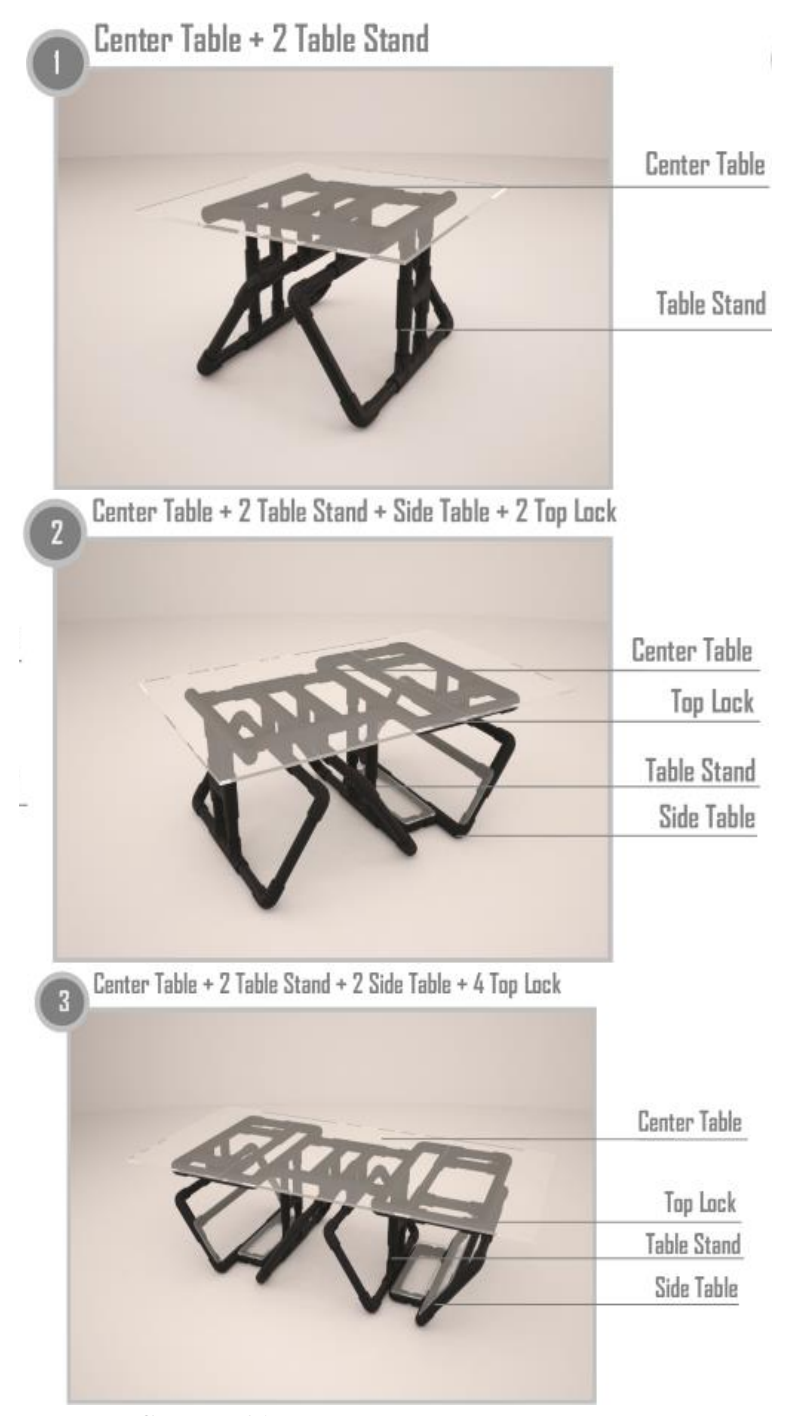

Gambar 21. Render Aplikasi Coffee Table
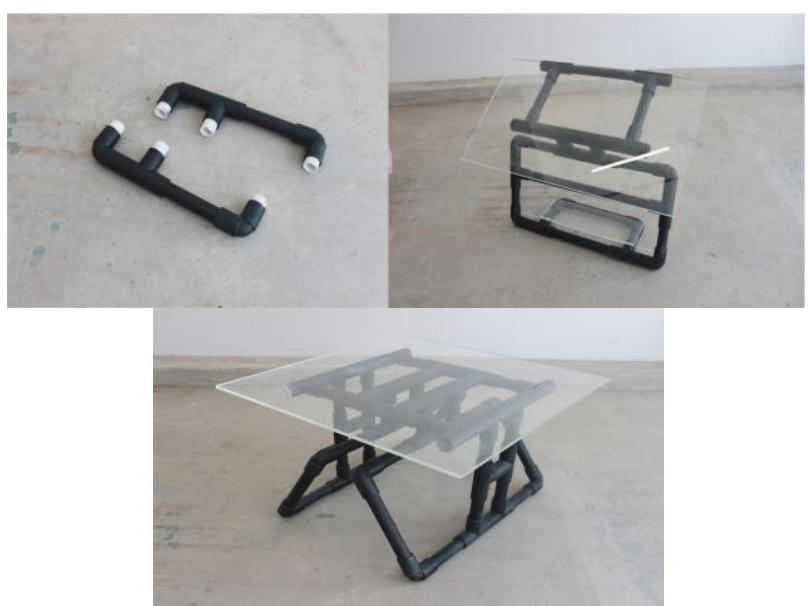

Gambar 22. Hasil Produksi Modul-modul Coffee Table

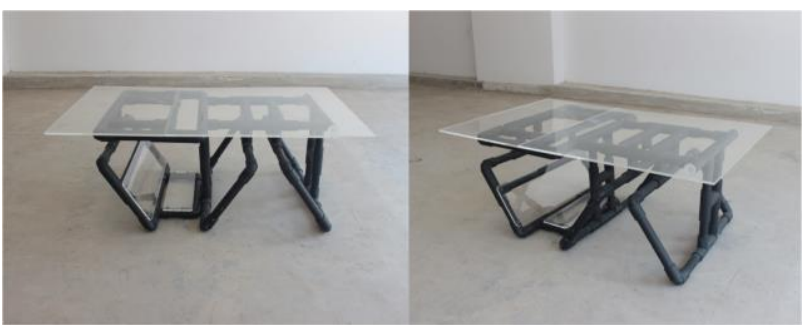

Gambar 23. Hasil Produksi PVC Coffee Table

\section{PVC Partition}

Secara garis besar, PVC Partition memiliki 2 komponen utama, yakni frame yang terdiri dari 3 modul (side frame, top frame, dan base frame) serta 3 modul pengisi/filling (full filling, half filling board, dan half filling mirror). Semua modul pada PVC partition dibuat dengan menerapkan lite finish. Untuk komponen filling, $P V C$ partition menggunakan bidang penutup yang terbuat dari multipleks dengan finishing HPL taco TH1211.

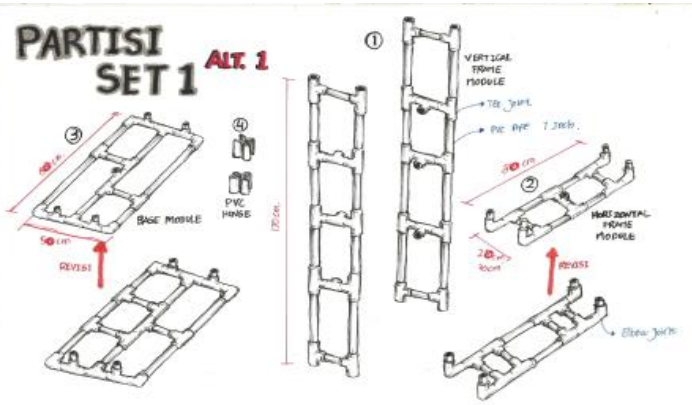

\section{PARTISI}

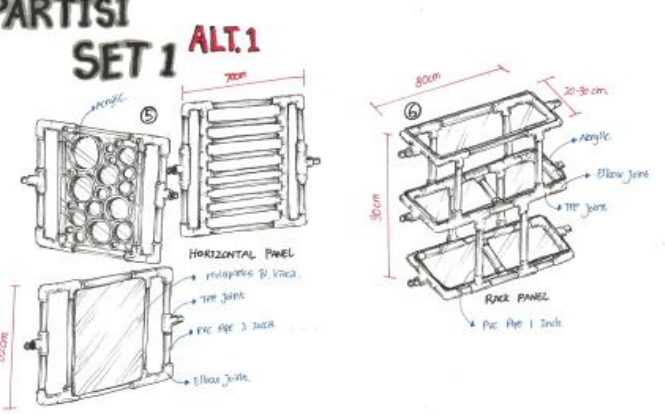

Gambar 24. Sketsa PVC Partition

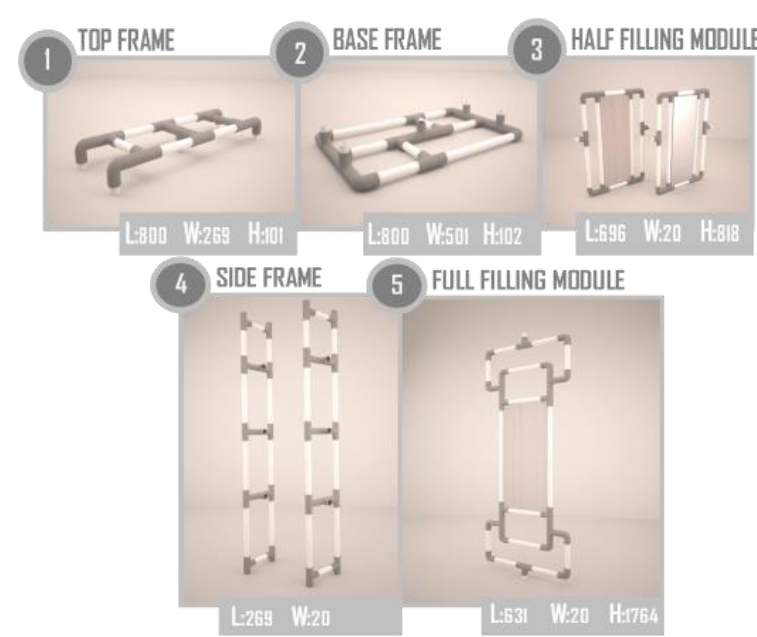

Gambar 25. Render Modul-modul PVC Partition

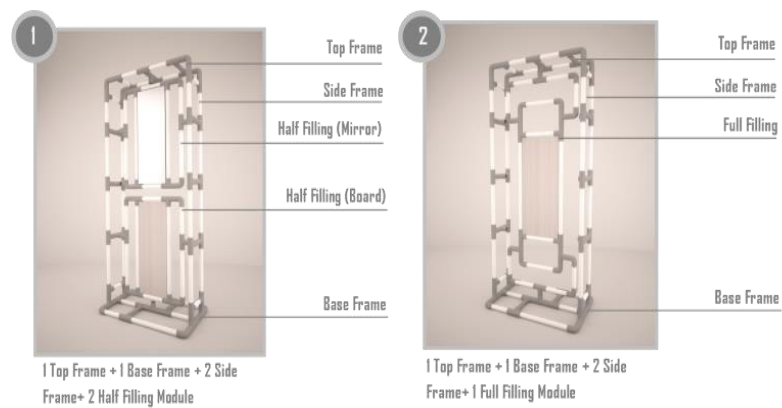

Gambar 26. Render Aplikasi Modul PVC Partition 


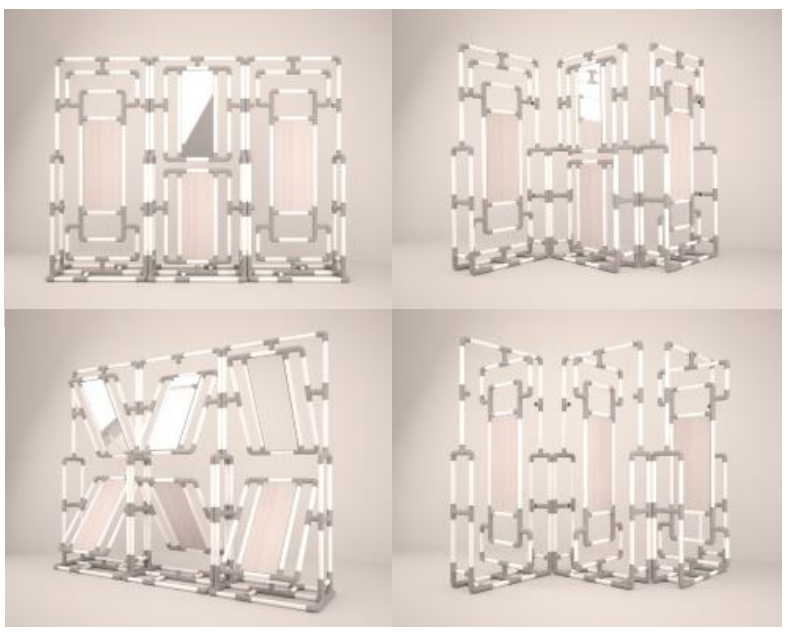

Gambar 27. Render Formasi Alternatif PVC Partition

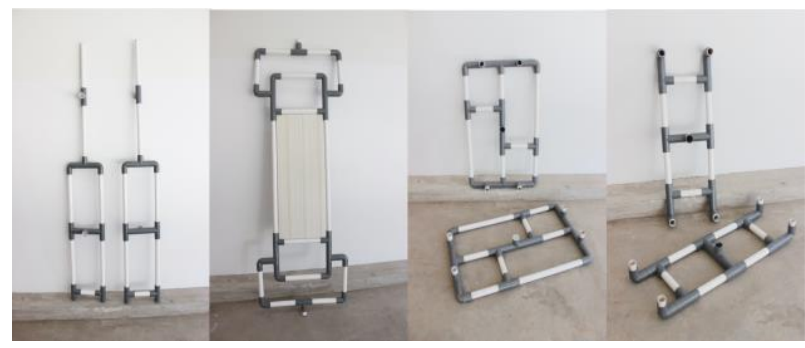

Gambar 28. Hasil Produksi Modul-modul PVC Partition

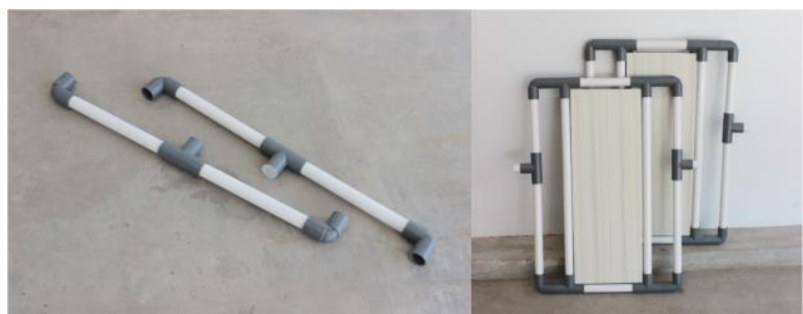

Gambar 29. Hasil Produksi Modul-modul PVC Partition

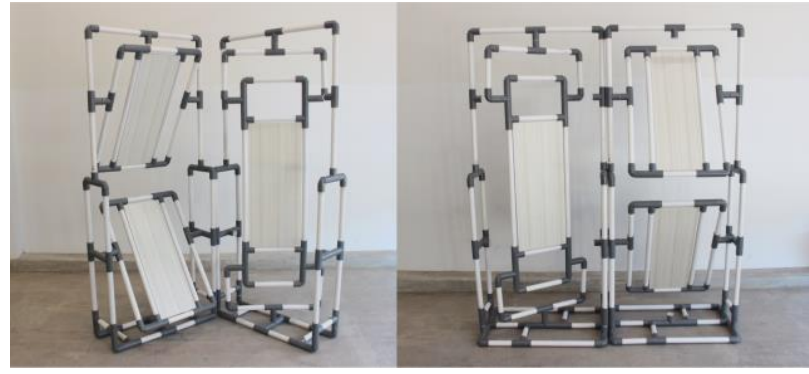

Gambar 30. Hasil Produksi PVC Partition

\section{PVC Stacking Rack}

Desain PVC stacking rack dirancang dengan kombinasi finishing dark brown pada komponen sambungan (joint) dan ivory pada komponen lonjor pipa $P V C$. Secara garis besar, $P V C$ stacking rack terdiri dari 2 modul utama (base module dan main module) serta 5 modul tambahan (increaser, top lock, tall separator, short separator, dan drawer). PVC stacking rack dapat dikonstruksi dengan main module hingga 5 tingkat diatas base module, disesuaikan dengan kebutuhan user. Dalam pembuatannya, PVC stacking rack juga menggunakan bahan tambahan seperti akrilik dan multipleks dengan finishing HPL taco TH1211 sebagai komponen pembentuk bidang.
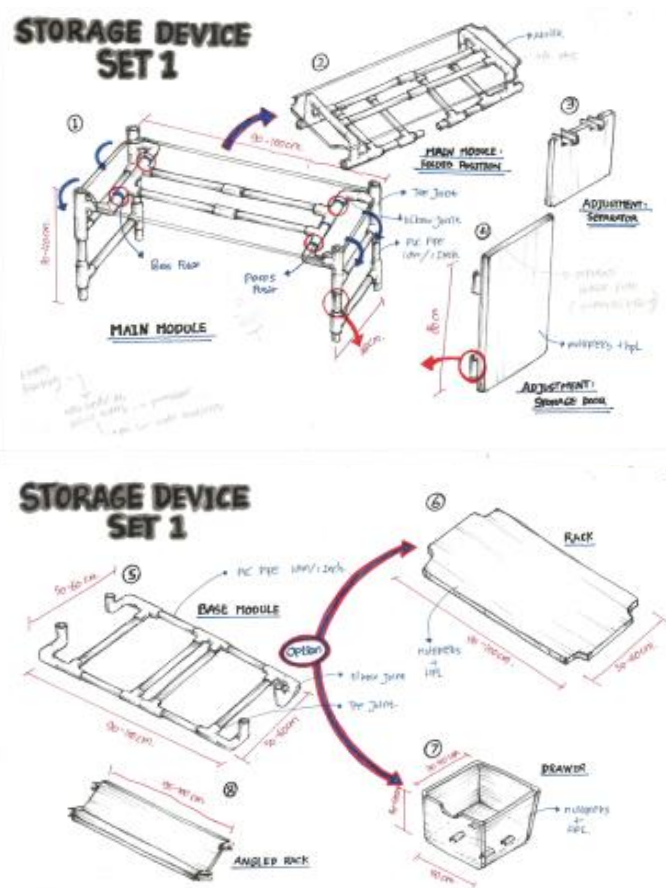

Gambar 31. Sketsa PVC Stacking Rack

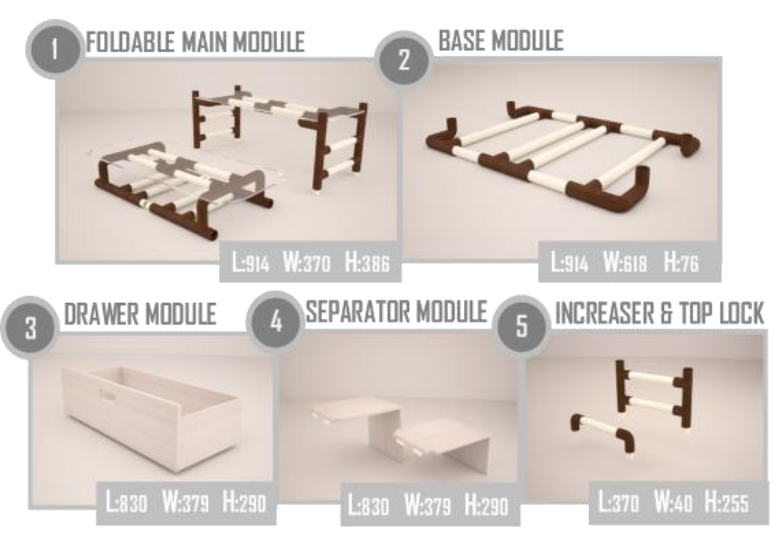

Gambar 32. Render Modul-modul PVC Stacking Rack 
Pramono: Eksperimen Perancangan Elemen Pembentuk Dan Pengisi Ruang Interior

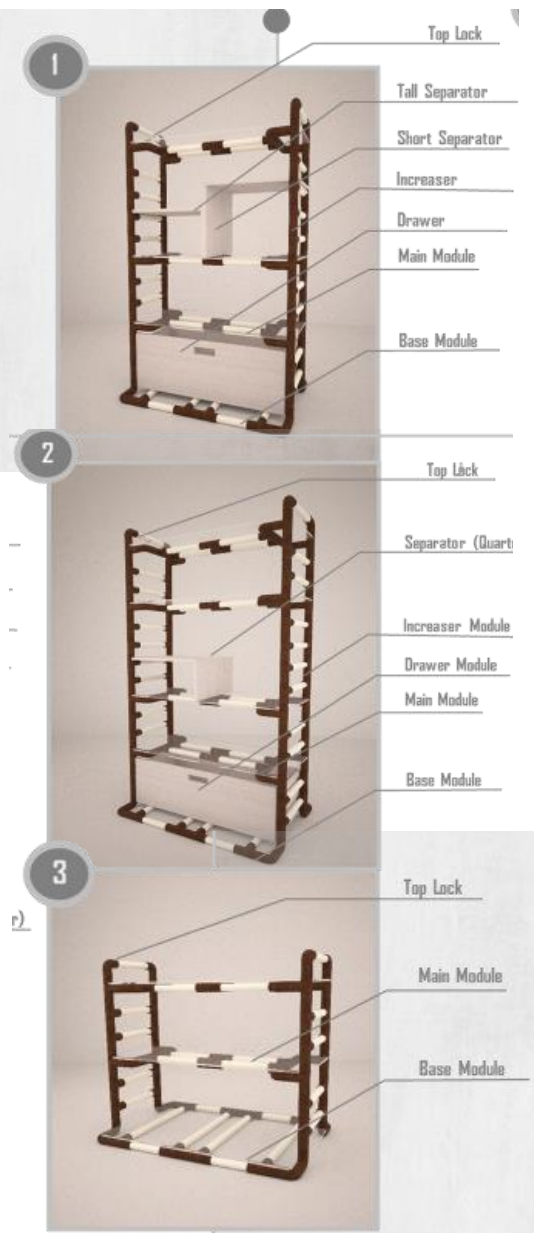

Gambar 33. Render Aplikasi Modul PVC Stacking Rack

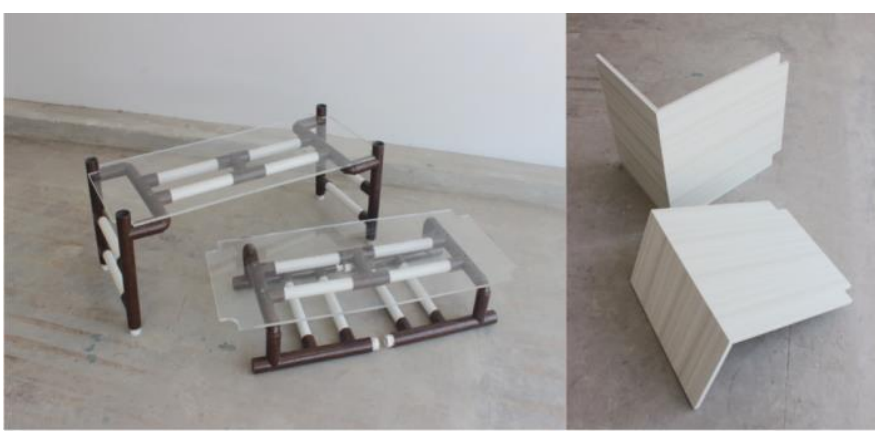

Gambar 34. Hasil Produksi Modul-modul PVC Stacking Rack.

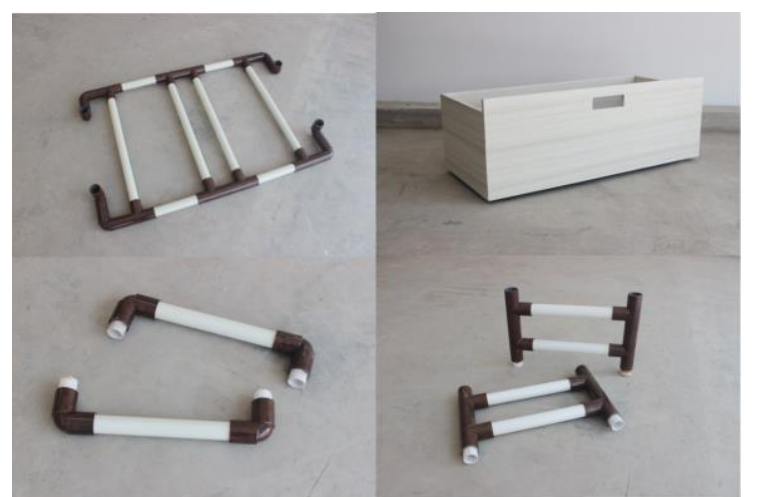

Gambar 35. Hasil Produksi Modul-modul PVC Stacking Rack.

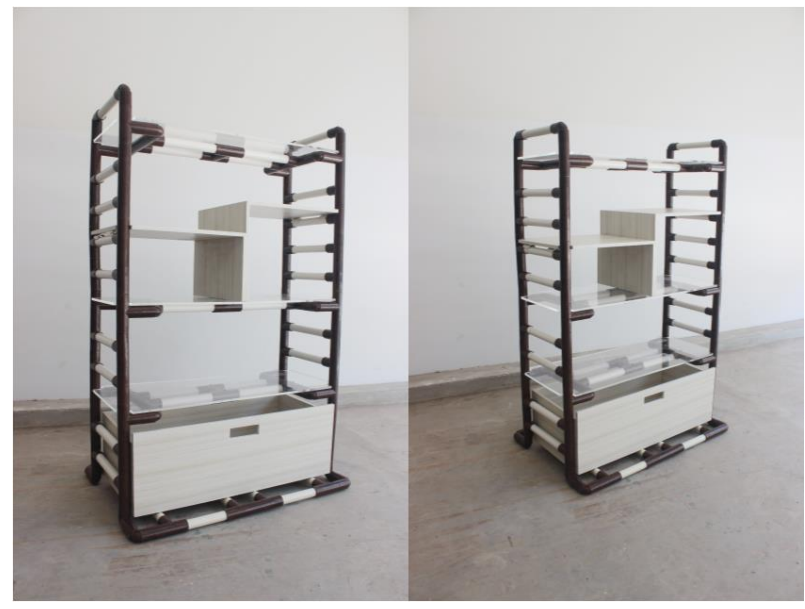

Gambar 36. Hasil Produksi PVC Stacking Rack

Kelima produk interior diatas juga dirancang untuk diaplikasikan pada rancangan booth pameran sebagai media implementasi. Dalam perancangan ini, terdapat 2 rancangan booth berukuran $4 \times 4 \mathrm{~m}$ yang telah dibuat sebagai display space untuk memamerkan produk interior yang telah diproduksi.

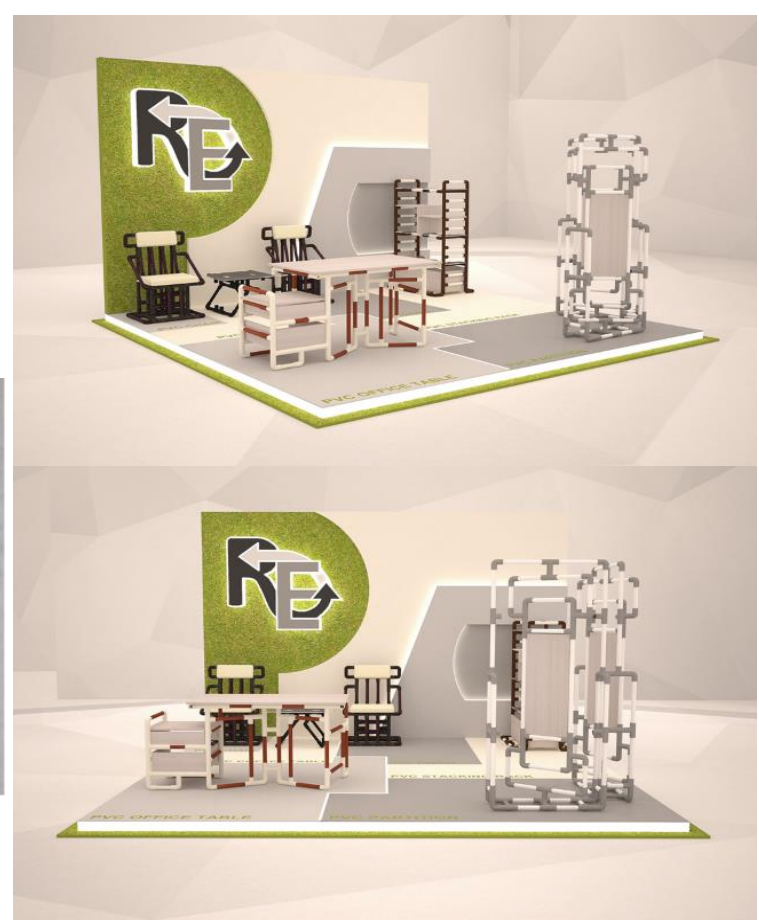

Gambar 37. Rancangan Booth Pameran 1 


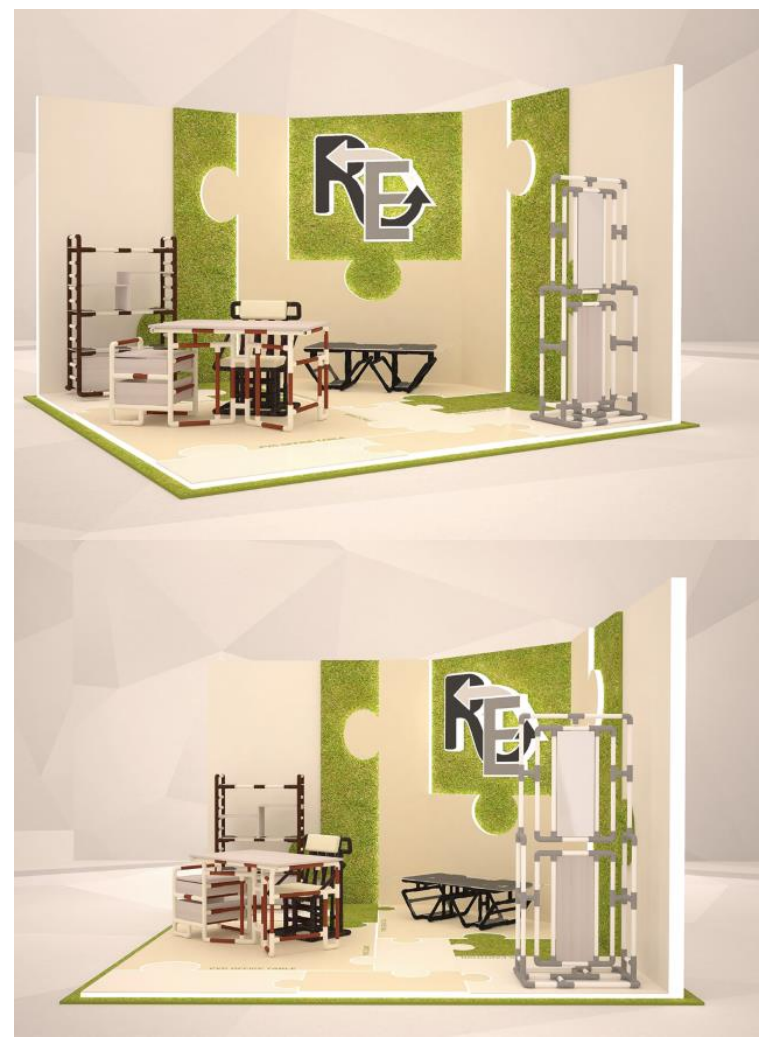

Gambar 38. Rancangan Booth Pameran 2

\section{SIMPULAN}

Eksperimen perancangan tugas akhir yang menerapkan prinsip repurposing material pipa $P V C$ menghasilkan 5 produk fungsional berupa chair, office table, coffee table, partisi, dan stacking rack. Perancangan kelima produk ini kelima desain produk ini membuktikan beberapa potensi repurposing pipa $P V C$ untuk dimanfaatkan menjadi elemen interior, yakni:

- Pipa $P V C$ merupakan material yang memiliki ketahanan terhadap air, korosi, dan merupakan isolator api sehingga sangat cocok difungsikan sebagai produk interior.

- Pipa $P V C$ diproduksi dengan standar pabrik sehingga memiliki konsistensi material dan ukuran yang baik. Pipa $P V C$ juga merupakan material yang dapat didaur ulang sehingga cukup sustainable.

- Pipa PVC memiliki sistem sambungan sehingga pemasangannya sangat mudah (hanya menggunakan lem) dan cepat (perakitan rata-rata hanya memakan waktu 1 hari).

- Dalam perancangan juga dibuktikan bahwa terdapat setidaknya 7 prosedur finishing yang dapat diterapkan pada permukaan pipa $P V C$ dan sambungannya. Finishing-finishing ini menerapkan berbagai teknik seperti teknik brush (untuk finishing woodstain), sphray (untuk finishing Solid color), dan pembakaran (untuk finishing bertekstur cracking).

Dari perancangan tugas akhir ini, dapat ditemukan beberapa kelebihan dari pipa $P V C$ ketika dimanfaatkan sebagai elemen interior, antara lain:
- Dari segi material, pipa $P V C$ memiliki ketahanan dan kekuatan yang cukup memadai untuk digunakan sebagai pembentuk elemen interior. Elemen interior dengan pipa $P V C$ sebagai material dasarnya juga cenderung mudah dan cepat dibuat. Lapisan plastik pada bagian luar pipa $P V C$ dan sambungannya juga dapat dimanfaatkan menjadi finishing burnt crack yang sangat otentik.

- Sambungan dan tabung pipa $P V C$ dapat dimanfaatkan untuk menghasilkan sistem mekanisme dan system modular yang terbukti dapat berfungsi dengan cukup baik menggantikan ring dan rel laci dengan harga yang jauh lebih murah.

Selain kelebihan, dapat juga dipetakan beberapa kekurangan dari pipa $P V C$ sebagai pembentuk elemen interior, antara lain:

- Dari segi sifat material, Pipa PVC memiliki kelenturan yang mengharuskan desainer memberikan banyak struktur pada rancangan produk. Pipa $P V C$ juga memiliki lapisan plastik yang mengurangi daya rekat lapisan finishing.

- Sistem mekanis baik putar maupun geser belum dapat berfungsi secara sempurna akibat dari kurangnya presisitas dan konstanitas bagian dalam sambungan pipa PVC.

- Dari sisi sistem modular, beberapa produk yang dikonstruksi dengan pipa $P V C$ masih sedikit goyah ketika digunakan akibat dari kurangnya kekuatan pada titik-titik pemasangan modul.

\section{REFERENSI}

[1] Agguire, Darinka. "Design for Repurposing: A Sustainable Design Strategy for Product Life and Beyond". Meksiko: Emily Carr University of Art + Design (2010) 2-3.

[2] PVC Pipe Association. "Handbook of PVC Pipe Design and Construction". Amerika Serikat: Industrial Press Inc (2012) 31-33.

[3] Arthur K-wlmderlich. "PVC Beach Swivel Chair". Amerika Serikat: US Patent no. 4842335 (1989).

[4] Livington, B. Bruce, Cottondale, Barry B. Livington; Mark S. Farmer. "Foldable Chair". Amerika Serikat: US Patent no. 6250712 (2001).

[5] Tenbl'oeck, Randy L. "PVC Rocking Chair". Amerika Serikat: US Patent no. 5678890 (1997). 